\title{
PEMANFAATAN KAPUR GAMPING SEBAGAI BAHAN TAMBAH PENGISI (FILLER) PADA CAMPURAN LATASTON HRS-WC (HOT ROLLED SHEET- WEARING COURSE
}

\author{
Andy Harisandy ${ }^{1}$, Robby ${ }^{2}$ dan Desriantomy ${ }^{3}$ \\ ${ }^{123}$ Program Studi Teknik Sipil, Fakultas Teknik, Universitas Palangka Raya \\ E-mail: andyharisandy22@gmail.com, robby@eng.upr.ac.id ${ }^{2}$,dan \\ desriantomy@yahoo.co.id ${ }^{3} /$ HP.+6281349767419 ${ }^{1}$
}

\begin{abstract}
ABSTRAK
Lataston HRS-WC adalah campuran aspal panas bergradasi senjang yang terdiri dari Agregat kasar, sedang, halus dan filler. Campuran ini banyak digunakan dilapangan sebagai lapis permukaan jalan. Pada pelaksanaannya dilapangan, pelaksana sering diperhadapkan dengan tidak tetapnya gradasi yang tersedia khususnya pada fraksi bahan pengisi (filler). Dalam komposisi campuran untuk material bahan pengisi (filler) dibutuhkan dalam jumlah yang cukup besar yaitu 6 $\%$ s/d $12 \%$. Material filler yang ada seperti abu batu dan semen memberikan harga yang cukup mahal. Abu kapur gamping memiliki ukuran partikel yang sangat halus, abu kapur gamping mengandung unsur pozzolan dan bersifat mengeras dan menambah kekuatan jika bereaksi dengan air. Dalam penelitian ini mencoba menganalisis penggunaan abu kapur dari Desa Sibung Kecamatan Raren Batuah Kapupaten Barito Timur Provinsi Kalimantan Tengah sebagai bahan pengisi (filler) pada campuran HRS-WC.bahan tambah pada campuran Lataston.
\end{abstract}

Kata kunci : Filler, Kapur Gamping, HRS-WC, Marshall

\begin{abstract}
Lataston HRS-WC is a gap graded hot mix asphalt consisting of coarse, medium, fine and filler aggregates. This mixture is widely used in the field as a road surface coating. In its implementation in the field, implementers are often faced with unstable gradations available, especially in the filler fraction. In the composition of the mixture for the filler material is needed in a large enough amount, namely 6\% to $12 \%$. Existing filler materials such as stone ash and cement provide a fairly expensive price. Limestone ash has a very fine particle size, limestone ash contains pozzolanic elements and is hardened and increases strength when reacted with water. In this study, we tried to analyze the use of limestone ash from Sibung Village, Raren Batuah District, East Barito Regency, Central Kalimantan Province as a filler in the HRS-WC mixture.
\end{abstract}

Keywords: Filler, Limestone, HRS-WC, Marshall 


\section{PENDAHULUAN}

\section{Latar Belakang}

Perkerasan jalan merupakan lapisan perkerasan yang terletak di antara lapisan tanah dasar dan roda kendaraan, yang berfungsi memberikan pelayanan kepada sarana transportasi, dan selama masa pelayanannya diharapkan tidak terjadi kerusakan yang berarti. Supaya perkerasan mempunyai daya dukung dan keawetan yang memadai, tetapi juga ekonomis, maka perkerasan jalan dibuat berlapis-lapis. Lapisan paling atas disebut juga lapisan permukaan, merupakan lapisan yang paling baik mutunya. Di bawahnya terdapat lapisan pondasi, yang diletakkan di atas tanah dasar yang telah dipadatkan Sukirman, (2003).

Kemajuan teknologi di segala bidang telah mendorong seluruh moda transportasi darat untuk lebih meningkatkan mutu, rehabilitas, dan perawatan fasilitas baik sarana maupun prasarana. Hal ini membuat kebutuhan akan material semakin meningkat seiring dengan banyaknya pembangunan jalan. Karena itu perlu adanya material alternatif yang dapat digunakan sebagai bahan campuran pembentuk lataston lapis permukaan ada beberapa jenis campuran aspal panas yang umum digunakan di Indonesia. Campuran aspal tesebut adalah :Laston (Lapis aspal Beton) atau AC(aspal Concrete), Lataston (Lapis Tipis aspal Beton) atau HRS ( Hot Rolled Sheet) dan Latasir ( Lapis Tipis Aspal Pasir) atau HRSS ( Hot Rolled Sand Sheet )

\section{Tujuan Penelitian}

1. Mengetahui sifat-sifat fisik dari penggunaan serbuk kapur gamping sebagai bahan tambah pengisi (Filler) pada campuran Hot Rolled Sheet Wearing Course (HRS-WC).

1. 2.Mengetahui proporsi dari komposisi yang digunakan pada campuran Hot Rolled Sheet-Wearing Course (HRS-WC)

2. 3.Mengetahui nilai karakteristik marshall campuran dan nilai kadar aspal Optimum (KAO) yang dihasilkan dari beberapa komposisi yang diteliti.

3. 4.Mengetahui pengaruh dari pengunaan campuran tersebut pada Lataston Lapis Aus (HRS-WC)

\section{METODE PENELITIAN}

\section{1) Umum}

Metode penelitian yang digunakan adalah metode uji laboratorium. Material yang akan digunakan dalam penelitian ini diperiksa terlebih dahulu di laboratorium untuk memperoleh karateristik dari material tersebut.

Data yang digunakan dilaboratorium digunakan untuk perencanaan campuran, selanjutnya dibuat benda uji (briket) sehingga diketahui karakteristik campuran.

\section{2) Lokasi dan Teknik Pengambilan Sampel}

Sampel berupa kapur diambil dari, Desa Sibung Kecamatan Raren Batuah Kabupaten Barito Timur Provinsi Kalimantan Tengah 


\section{3) Metode Pengambilan Data}

Pengambilan data dilakukan dengan membuat briket/benda uji sebanyak 15 buah briket/benda uji untuk mencari (KAO) pada komposisi $100 \%$ pasir alam dari Desa Taringen, dengan 5 variasi kadar aspal, 5,5\%,6\%,6,5\%,7\%,,5\% (3 briket/benda uji tiap kadar aspal). Metode pembuatan benda uji briket atau analisis pengujian Marshall mengacu pada prosedur Spesifikasi Bina Marga divisi 6

\section{HASIL DAN PEMBAHASAN}

Hasil pemeriksaan gradasi dapat dilihat pada tabel berikut ini.

Tabel 1. Hasil Pemeriksaan Gradasi (Analisa Saringan)

\begin{tabular}{|c|c|c|c|c|}
\hline \multirow{2}{*}{ No. Saringan } & \multicolumn{3}{|c|}{ Persentase Lolos Saringan (\%) } \\
\cline { 3 - 5 } inch & mm & $\begin{array}{c}\text { Eks. Merak } \\
\text { Agregat } \\
\text { Kasar }\end{array}$ & Abu Batu & Eks. Tangkiling \\
\hline$\# 3 / 4$ & 19 & 100,00 & 100,00 & 100,00 \\
\hline$\# 1 / 2$ & 12,7 & 77,76 & 100,00 & 100,00 \\
\hline$\# 3 / 8$ & 9,5 & 52,16 & 100,00 & 100,00 \\
\hline No.8 & 2,38 & 2,77 & 86,19 & 92,92 \\
\hline No.30 & 0,595 & 1,43 & 50,04 & 54,40 \\
\hline No.200 & 0,074 & 0,00 & 4,83 & 8,58 \\
\hline
\end{tabular}

Sumber: Hasil Pemeriksaan Laboratorium (2021)

Pemeriksaan sifat-sifat fisik agregat yang lain yaitu pemeriksaan berat jenis, penyerapan, sand equivalent dapat dilihat pada tabel berikut.

Tabel 2. Hasil Pemeriksaan Sifat-sifat Fisik Agregat

\begin{tabular}{|l|c|c|c|c|}
\hline \multirow{2}{*}{\multicolumn{1}{|c|}{ Pemeriksaan }} & \multicolumn{2}{|c|}{ Eks. Merak } & \multirow{2}{*}{ Pasir } & \multirow{2}{*}{ Spesifikasi } \\
\cline { 2 - 3 } & $\begin{array}{c}\text { Agregat } \\
\text { Kasar }\end{array}$ & $\begin{array}{c}\text { Abu } \\
\text { Batu }\end{array}$ & & - \\
\hline Berat Jenis & 4,13 & 2,80 & 2,73 & - \\
\hline $\begin{array}{l}\text { Berat Jenis Kering } \\
\text { Permukaan }\end{array}$ & 4,21 & 2.82 & 2,81 & - \\
\hline Berat Jenis Semu & 2,35 & 2,86 & 2,95 & Min. 2,5 \\
\hline Penyerapan (\%) & 2,84 & 0,77 & 2,65 & Maks. 3 \\
\hline Keausan / Abrasi (\%) & 21,17 & - & - & Maks. 40 \\
\hline Sand Equivalent (\%) & - & - & 93,26 & Min. 60 \\
\hline
\end{tabular}

Sumber: Hasil Pemeriksaan Laboratorium (2021) 
JURNAL KACAPURI

JURNAL KEILMUAN TEKNIK SIPIL

Volume 4 Nomor 2 Edisi Desember 2021

Setelah Pengujian material, dilanjutkan dengan perhitungan perencaan campuran antara agregat, Dalam hal ini metode memproposikan agregat mengunakan cara diagonal dan coba-coba (Trial and Error) yaitu berdasarkan gradasi ideal (batas tengah) dari spesifikasi gradasi yang memenuhi spesifikasi Lataston (HRS-WC). Hasil perhitungan dan grafik pada komposisi ini.

Tabel 3. Hasil Perhitungan Gradasi Gabungan Metode Diagonal

\begin{tabular}{|c|c|c|c|c|c|c|c|c|c|}
\hline \multicolumn{2}{|c|}{ No. Saringan } & \multicolumn{2}{c|}{$\begin{array}{c}\text { Agregat Kasar } \\
\text { (CA) }\end{array}$} & \multicolumn{2}{c|}{$\begin{array}{c}\text { Abu Batu } \\
(\mathrm{FA})\end{array}$} & \multicolumn{2}{c|}{$\begin{array}{c}\text { Pasir } \\
(\mathrm{SA})\end{array}$} & $\begin{array}{c}\text { Total } \\
\text { Kombinasi }\end{array}$ & Spesifikasi \\
\hline Inch & $\mathrm{mm}$ & \multicolumn{2}{|c|}{$34 \%$} & \multicolumn{2}{|c|}{$23 \%$} & \multicolumn{2}{|c|}{$43 \%$} & 100,00 & 100,00 \\
\hline$\# 3 / 4$ & 19 & 100,00 & 32,00 & 100,00 & 23,00 & 100,00 & 45,00 & 100,00 \\
\hline$\# 1 / 2$ & 12,7 & 77,76 & 24,88 & 100,00 & 23,00 & 100,00 & 45,00 & 92,88 & $90-100$ \\
\hline$\# 3 / 8$ & 9,5 & 52,16 & 16,69 & 100,00 & 23,00 & 100,00 & 45,00 & 84,69 & $75-85$ \\
\hline No.8 & 2,38 & 2,77 & 0,89 & 86,19 & 19,82 & 92,92 & 41,81 & 62,52 & $50-72$ \\
\hline No.30 & 0,595 & 1,43 & 0,46 & 50,04 & 11,51 & 54,40 & 24,48 & 36,45 & $35-60$ \\
\hline No.200 & 0,074 & 0,00 & 0,00 & 4,83 & 1,11 & 8,58 & 3,86 & 4,97 & $6 .-10$ \\
\hline Pan & - & 0,00 & 0,00 & 0,00 & 0,00 & 0,00 & 0,00 & 0,00 & 0 \\
\hline
\end{tabular}

Sumber: Hasil Perhitungan (2021)

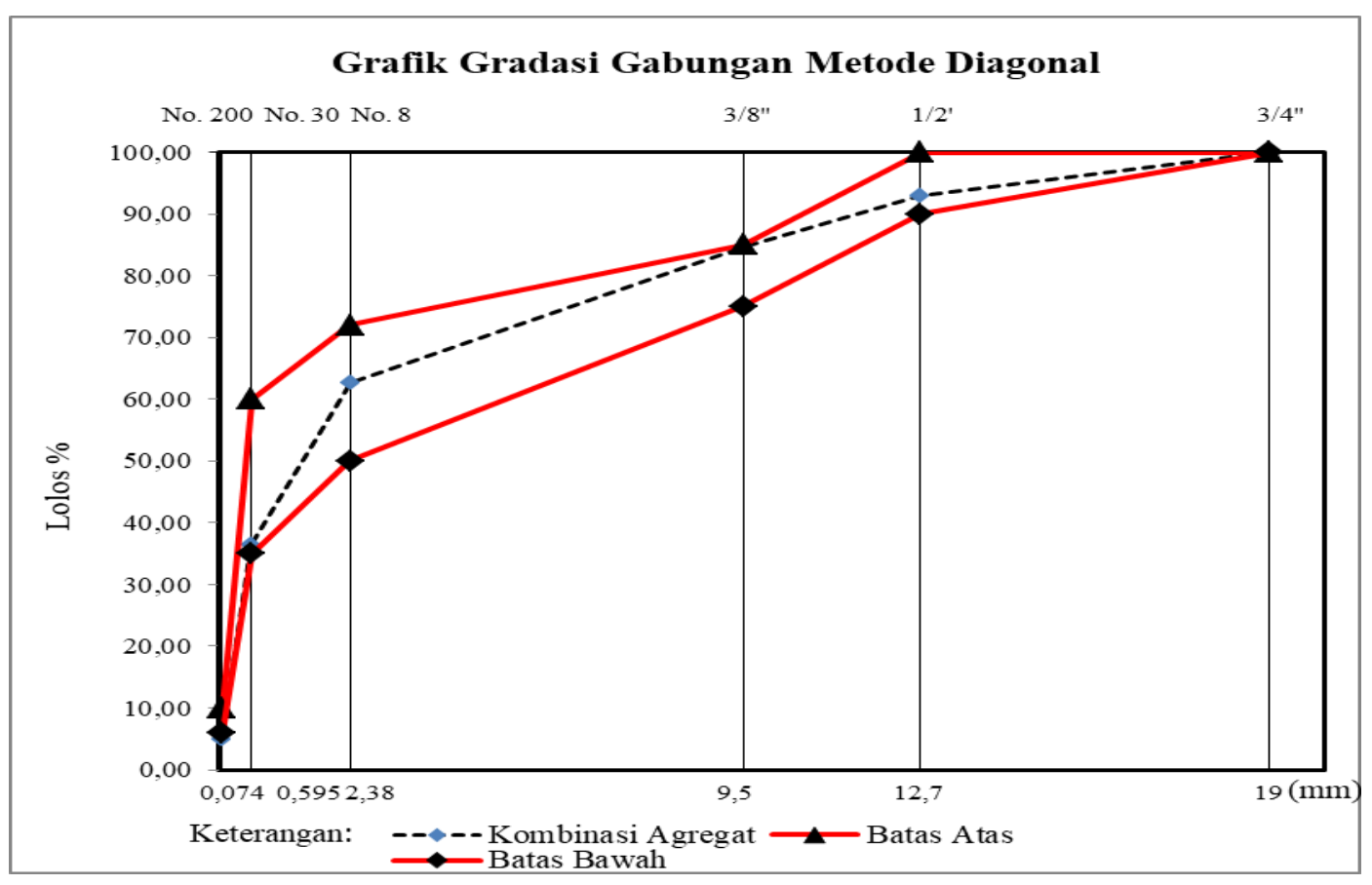

Gambar 1. Grafik Gradasi Gabungan Metode Diagonal 
B. Perencanaan campuran cara Trial and Error

Hasil perhitungan komposisi gradasi agregat gabungan dengan cara diagonal yang sudah diperoleh dikontrol menggunakan cara coba-coba (Trial and Error). Hasil perhitungan untuk proporsi campuran cara coba-coba (Trial and Error) dapat Berdasarkan proporsi yang telah ditetapkan, selanjutnya dilakukan perhitungan berat material dan aspal untuk pembuatan benda uji.

Tabel 4. Hasil Perhitungan Gradasi Gabungan cara Trial and Error

\begin{tabular}{|c|c|c|c|c|c|c|c|c|c|}
\hline \multicolumn{2}{|c|}{ No. Saringan } & \multicolumn{2}{c|}{$\begin{array}{c}\text { Agregat Kasar } \\
\text { (CA) }\end{array}$} & \multicolumn{2}{c|}{$\begin{array}{c}\text { Abu Batu } \\
\text { (FA) }\end{array}$} & \multicolumn{2}{c|}{$\begin{array}{c}\text { Pasir } \\
(\mathrm{SA})\end{array}$} & $\begin{array}{c}\text { Total } \\
\text { Kombinasi }\end{array}$ & Spesifikasi \\
\hline Inch & $\mathrm{mm}$ & \multicolumn{2}{|c|}{$36 \%$} & \multicolumn{2}{c|}{$30 \%$} & \multicolumn{2}{c|}{$34 \%$} & & \\
\hline$\# 3 / 4$ & 19 & 100,00 & 36,00 & 100,00 & 30,00 & 100,00 & 34,00 & 100,00 & 100,00 \\
\hline$\# 1 / 2$ & 12,7 & 77,76 & 27,99 & 100,00 & 30,00 & 100,00 & 34,00 & 95,01 & $90-100$ \\
\hline$\# 3 / 8$ & 9,5 & 52,16 & 18,78 & 100,00 & 30,00 & 100,00 & 34,00 & 82,78 & $75-85$ \\
\hline No.8 & 2,38 & 2,77 & 1,00 & 86,19 & 25,86 & 92,80 & 31,55 & 58,40 & $50-72$ \\
\hline No.30 & 0,595 & 1,43 & 0,52 & 50,04 & 15,01 & 53,50 & 18,19 & 40,72 & $35-60$ \\
\hline No.200 & 0,074 & 0,00 & 0,00 & 4,83 & 1,45 & 7,68 & 2,61 & 4,06 & $6 .-10$ \\
\hline Pan & - & 0,00 & 0,00 & 0,00 & 0,00 & 0,00 & 0,00 & 0,00 & 0 \\
\hline
\end{tabular}

Sumber: Hasil Perhitungan (2021)

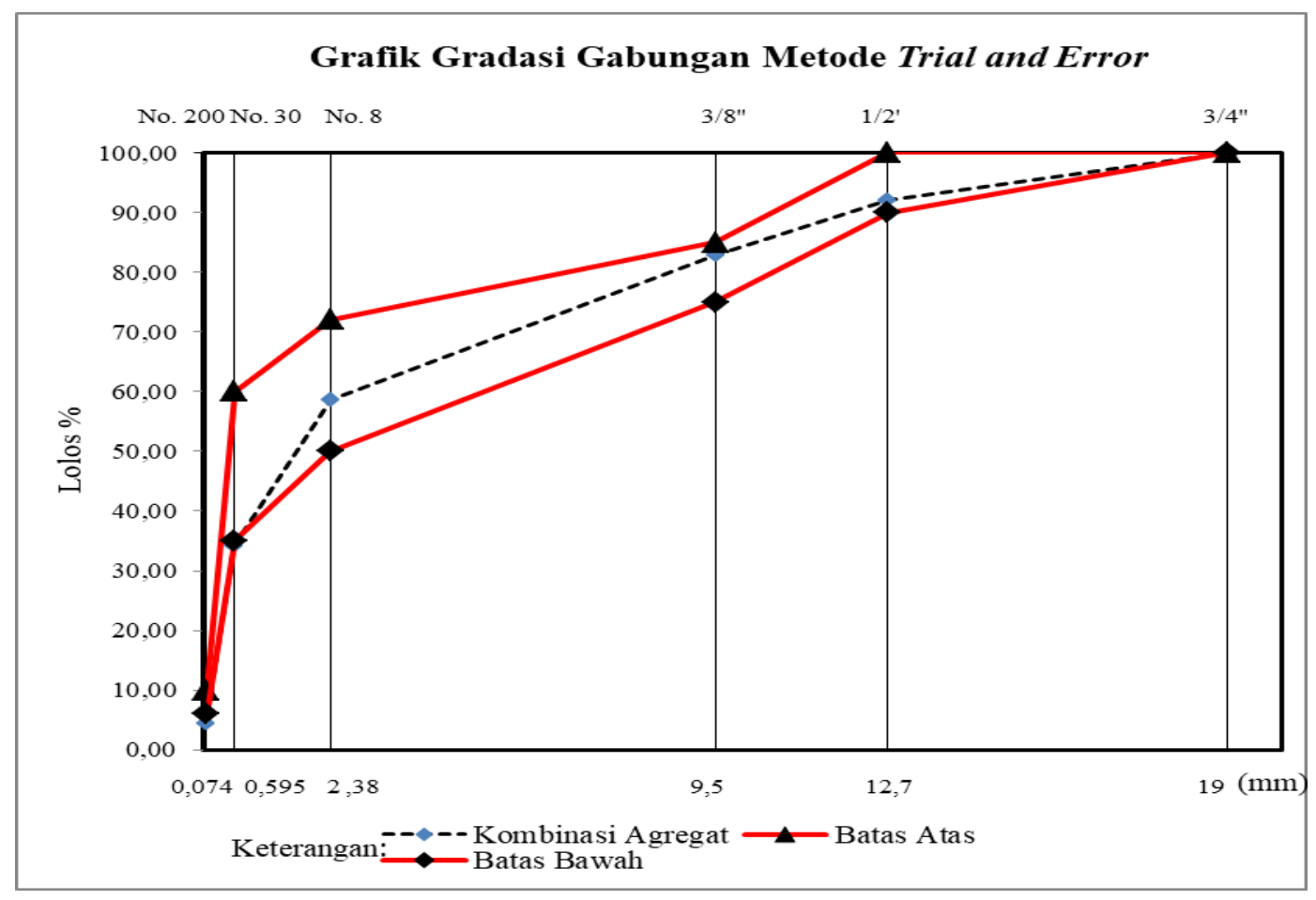

Gambar 2. Grafik Gradasi Gabungan Metode Trial and Error 
Dari hasil perhitungan gradasi gabungan untuk komposisi campuran dengan menggunakan perhitungan metode diagonal maupun dengan menggunakan metode Trial and error diperoleh hasil bahwa yang lolos saringan No. 200 tidak memenuhi spesifikasi yaitu minimal $6 \%$ dan maksimal 10\%. Hasil perhitungan dengan cara trial and error menunjukkan yang lolos saringan No. 200 sebesar $4,06 \%$ dari total keseluruhan agregat. Hal inipun menjadi alasan dilakukannya penambahan Serbuk kapur gamping sebagai bahan pengisi (Filler) atau bahan yang lolos saringan No.200

Tabel 5. Rencana Komposisi Campura

\begin{tabular}{|c|c|c|c|c|c|c|c|c|c|c|c|}
\hline \multicolumn{6}{|c|}{ Berat Total Agregat 1200 gram } & \multirow{3}{*}{$\begin{array}{l}\text { Berat Total } \\
\text { Agregat }\end{array}$} & \multicolumn{5}{|c|}{ Variasi Kadar Aspal } \\
\hline \multirow{2}{*}{\multicolumn{2}{|c|}{$\begin{array}{l}\text { Agregat } \\
\text { Kasar }\end{array}$}} & \multirow{2}{*}{\multicolumn{2}{|c|}{ Abu Batu }} & \multirow{2}{*}{\multicolumn{2}{|c|}{ Pasir }} & & $5,5 \%$ & $6 \%$ & $6,5 \%$ & $7 \%$ & $7,5 \%$ \\
\hline & & & & & & & \multicolumn{5}{|c|}{$\begin{array}{l}\text { Berat Kadar Aspal Terhadap Total } \\
\text { Campuran }\end{array}$} \\
\hline$\%$ & gram & $\%$ & gram & $\%$ & gram & Gram & \multicolumn{5}{|c|}{ gram } \\
\hline 36 & 432 & 30 & 360 & 34 & 408 & 1200 & 69,84 & 76,60 & 83,42 & 90,32 & 97,30 \\
\hline
\end{tabular}

Sumber: Hasil Perhitungan (2021)

Tabel 6. Hasil Pengujian Marshall

\begin{tabular}{|c|c|c|c|c|c|c|}
\hline \multirow{2}{*}{$\begin{array}{c}\text { Kadar Aspal } \\
(\%)\end{array}$} & \multicolumn{5}{|c|}{ Parameter Marshall } & \multirow[t]{2}{*}{ Keterangan } \\
\hline & $\begin{array}{l}\text { Stabilitas } \\
\quad(\mathrm{kg})\end{array}$ & $\begin{array}{l}\text { VIM } \\
(\%)\end{array}$ & $\begin{array}{l}\text { VMA } \\
(\%)\end{array}$ & $\begin{array}{l}\text { VFB } \\
(\%)\end{array}$ & $\begin{array}{c}\mathrm{MQ} \\
(\mathrm{kN} / \mathrm{mm})\end{array}$ & \\
\hline 5,5 & 575,630 & 8,89 & 20,857 & 57,38 & 231,653 & $\begin{array}{c}\text { Stabilitas, Flow } \\
\text { VIM,VFB, Tidak } \\
\text { Memenuhi Spesifikasi }\end{array}$ \\
\hline 6 & 676,122 & 7.80 & 20,474 & 62,88 & 241.440 & $\begin{array}{c}\text { VIM,VFB, Tidak } \\
\text { Memenuhi Spesifikasi }\end{array}$ \\
\hline 6,5 & 839,203 & 6,95 & 21,184 & 67,45 & 262,531 & $\begin{array}{l}\text { Stabilitas, VMA, } \\
\text { Tidak Memenuhi }\end{array}$ \\
\hline 7 & 885,293 & 4,93 & 22,125 & 77,23 & 271,801 & Memenuhi Spesifikasi \\
\hline 7,5 & 807,468 & 4,19 & 21,404 & 80,73 & 269,223 & Memenuhi Spesifikasi \\
\hline Spesifikasi & $>600$ & $4-6$ & $17 \mathrm{Mim}$ & $>68$ & $>250$ & \\
\hline
\end{tabular}

Sumber: Hasil Pengujian Marshal (2021)

Hasil pengujian Marshall tanpa penambahan abu kapur gamping sebagai bahan pengisi menunjukkan bahwa pada kadar aspal $7 \%$ dan $7,5 \%$, campuraan aspal tersebut memenuhi spesifikasi terhadap semua parameter Mashall, sedangkan pada kadar aspal 5,5\%, 6\% dan 6,5\% beberapa parameter Marshall pada campuran aspal tersebut tidak memenuhi spesifikasi. 


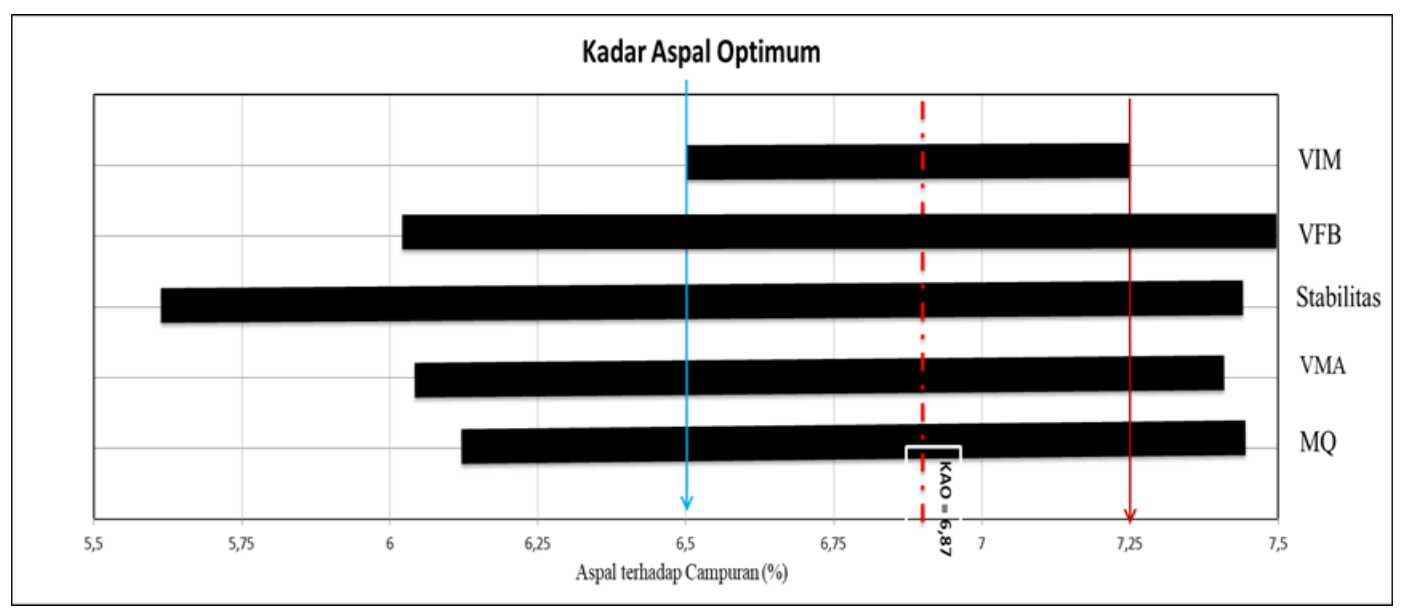

Gambar 3. Grafik Hubungan Nilai Kadar terhadap Parameter Marshall

Berdasarkan hasil evaluasi sifat karakteristik Marshall menunjukkan bahwa rentang kadar aspal 6,5\% hingga 7,5\% campuran memenuhi semua persyaratan yang ditentukan. Berdasarkan rentang tersebut diambil nilai tengah rentang yaitu 6,87 \% sebagai nilai Kadar Aspal Optimum (KAO). Dari hasil pengujian maka didapat hasil

Tabel 7, Nilai Parameter Marshall pada Kadar Aspal Optimum

\begin{tabular}{|c|l|c|c|c|}
\hline No. & \multicolumn{1}{|c|}{$\begin{array}{c}\text { Karakteristik } \\
\text { Marshall }\end{array}$} & Nilai & Persyaratan & Satuan \\
\hline 1 & Stabilitas & 885,923 & $>600$ & $\mathrm{Kg}$ \\
\hline 2 & VMA & 21,434 & 17 & $\%$ \\
\hline 3 & VIM & 5,79 & $3-5$ & $\%$ \\
\hline 4 & VFB & 73,09 & $>68$ & $\%$ \\
\hline 5 & Hasil Bagi Marshall & 261,728 & $\geq 250$ & $\mathrm{~kg} / \mathrm{m}$ \\
\hline
\end{tabular}

Sumber: Hasil Perhitungan Marshall

\section{PENUTUP}

\section{Kesimpulan}

Berdasarkan hasil penelitian dan pembahasan yang telah diuraikan sebelumnya, pada "Penggunaan Abu kapur gamping Sebagai tambah Pengisi (Filler) Pada Campuran Lataston Lapis Aus (Hot Rolled Sheet - Wearing Course)" ini dapat disimpulkan beberapa hal sebagai berikut:

1. Material penyusun dalam perencanaan campuran Hot Rolled Sheet Wearing Course (HRS-WC) dari hasil pemeriksaan sifat-sifat fisik agregat berupa pemeriksaan gradasi (analisa saringan), berat jenis, penyerapan dan keausan agregat kasar semuanya memenuhi persyaratan spesifikasi, sedangkan Abu Kapur Gamping yang digunakan sebagai bahan tambah Filler telah memenuhi spesifikasi Umum Bina Marga (2018) divisi 6 yaitu lolos saringan No.200. abu kapur gamping 
2. Komposisi terbaik yang dihasilkan dalam perencanaan campuran Hot Rolled Sheet- Wearing Course terdiri dari $36 \%$ agrega kasar, 30\% abu batu dan $34 \%$ pasir. Pada perencanaan komposisi campuran Hot Rolled SheetWearing Course yang diperoleh terdapat agregat yang lolos saringan No.200 atau bahan pengisi masih belum memenuhi spesifikasi Bina Marga (2018) revisi 2 yaitu minimal $6 \%$ dan maksimal $10 \%$ dari total berat agregat, hal ini menjadi alasan di lakukan penambahan bahan pengisi (filler) yang dalam penelitian ini menggunakan abu kapur gamping.

3. Hasil Penelitian terhadap parameter karakteristik Marshall tanpa penambahan bahan pengisi (filler) menggunakan komposisi campuran terbaik dengan Kadar Aspal Optimum (KAO) senilai 6,87\% diperoleh nilai karakteristik parameter Marshall sebagai berikut :

a. Nilai stabilitas pada Kadar Aspal Optimum tanpa penambahan bahan pengisi (Filler) diperoleh nilai stabilitas sebesar 853,100 kg.

b. Nilai kelelehan (flow) pada Kadar Aspal Optimum tanpa penambahan bahan pengisi (Filler) diperoleh nilai kelelehan sebesar 3,27 mm.

c. Nilai rongga udara dalam campuran (VIM) pada Kadar Aspal Optimum tanpa penambahan bahan pengisi (Filler) diperoleh nilai VIM sebesar $6,62 \%$.

d. Nilai rongga terisi aspal (VFB) pada Kadar Aspal Optimum tanpa penambahan bahan pengisi (Filler) diperoleh nilai VFB sebesar 73,38 \%.

e. Nilai hasil bagi Marshall (Marshall Quotient) pada Kadar Aspal Optimum tanpa penambahan bahan pengisi (Filler) diperoleh nilai sebesar294,048 g/mm.

4. Hasil penelitian terhadap Parameter karakteristik Marshall menggunakan komposisi campuran yang sama dan kadar Aspal Optimum (KAO) senilai 6,87\% dengan penambahan bahan pengisi menggunakan abu kapur gamping dengan variasi penambahan $6 \%, 7 \%, 8 \%, 9 \%$ dan $10 \%$ dihasilkan nilai karakterisitik parameter Marshall sebagai berikut :

a. Nilai stabilitas untuk semua variasi kadar penambahan abu kapur gamping memenuhi nilai spesifikasi yang disyaratkan. Nilai stabilitas tertinggi terdapat pada $10 \%$ penambahan abu kapur gamping yaitu

b. Nilai rongga udara dalam campuran (VIM) untuk semua variasi penambahan abu kapur gamping yaitu 6\%, 7\%, 8\%, 9\% dan 10\% semua memenuhi spesifikasi yang di ijinkan yaitu 3\%-5. Nilai rongga udara dalam campuran (VIM) yang dihasilkan cenderung menurun seiring dengan semakin besarnya penambahan abu kapur gamping yang digunakan.

c. Nilai rongga udara terisi aspal (VFB) untuk semua variasi penambahan abu terbang batubara memenuhi spesifikasi yang disyaratkan. Nilai rongga terisi aspal (VFB) tertinggi terdapat pada penambahan abu kapur gamping $10 \%$ yaitu sebesar $79,72 \%$. Nilai rongga terisi aspal mengalami penigkatan seiring dengan bertambahnya abu terbang batubara yang digunakan.

d. Nilai hasil bagi Marshall (Marshall Quotient) untuk semua variasi penambahan kapur gamping memenuhi spesifikasi yang disyaratkan. Nilai hasil bagi Marshall (Marshall Quotient) tertinggi terdapat pada 
penambahan abu kapur gamping $10 \%$ yaitu sebesar 398,721 kN/mm dan nilai terendah yaitu pada penambahan abu terbang batubara $6 \%$ dengan nilai hasil bagi Marshall (Marshall Quotient) sebesar 261,728 kN/mm.

5. Berdasarkan hasil penelitian yang sudah dilakukan terhadap parameter karakteristik Marshall dengan variasi penambahanabu kapur gamping dengan menggunakan grafik hubungan antara parameter campuran aspal dengan persentase penambahan kapur gamping yang digunakan untuk menentukan kadar abu kapur gamping maksimum. Didapatkan penambahan abu kapur gamping sebesar 4,25\%. Nilai parameter karakteristik Marshall pada penambahan abu kapur gamping maksimum menghasilkan nilai stabilitas sebesar 1030,00 kg, nilai VIM sebesar 3,8 \%, nilai VFB sebesar 73,39 \% dan nilai hasil bagi Marshall sebesar 398,721 kg/mm. Penggunaan abu kapur gamping sebagai tambahan filler dapat mempengaruhi parameter karakteristik Marshall nilai stabilitas naik sebesar 18,25\% dari nilai stabilitas campuran tanpa menggunakan kapur gamping sebagai bahan tambah Filler yaitu rongga dalam campuran (VIM) mengalami penurunan sebesar $0,95 \%$, rongga terisi aspal (VFB) mengalami kenaikan sebesar 6,00\% dan hasil bagi Marshall mengalami kenaikan sebesar $85,5 \mathrm{~kg} / \mathrm{mm}$.

\section{Saran}

Berdasarkan kesimpulan yang diperoleh dalam penelitian ini, dapat disampaikan beberapa saran sebagai berikut:

1. Dari hasil perencanaan Campuran HRS - WC (Hot Rolled Sheet -Wearing Course) ini dapat disarankan, untuk penelitian selanjutnya dapat dikembangkan pada jenis perkerasan yang lain dan pada dasarnya diharapkan dapat menghasilkan suatu lapis perkerasan yang baik dan memenuhi spesifikasi.

2. Untuk mendapatkan hasil penelitian yang lebih dan akurat harus selalu berpedoman pada prosedur-prosedur yang telah ditentukan dan perlu ketelitian yang tinggi dalam pemeriksaan bahan, perhitungan, perencanaan campuran, pengujian hasil campuran karena akan berpenga-ruh pada hasil akhir yang akan dicapai.

3. Dari penelitian ini diharapkan dapat juga memberikan alternatif lain pada perkerasan aspal sehingga dapat memikirkan kembali penggunaan semen yang harganya cukup mahal dan penggunaan abu kapur gamping bisa digunakan d alam perencanaan campuran dan perkerasan. 


\section{DAFTAR PUSTAKA}

Charles, J.S (2008), dalam penelitian Tugas Akhir berjudul "Analisa Kinerja Lataston Lapis Aus (HRS-WC) Yang Menggunakan Abu Batu Kapur Sebagai Tambahan Filler Dari Daerah Puruk Cahu Kabupaten Murung Raya", Penelitian ini dilakukan di Laboraturium Jalan Raya Fakultas Teknik Universitas Palangka Raya

Desriantomy (2007), Penuntun Praktikum Bahan Perkerasan Jalan Raya, Fakultas Teknik Universitas Palangka Raya.

Dahlia, A (2007), Pengaruh Penggunaan Portland Cement (PC) Dan Portland Pozzoland Cement (PPC) Sebagai Tambahan Filler Pada Campuran Aspal Panas Jenis HRS WC, Tugas Akhir Fakultas Teknik Universitas Palangka Raya, Palangka Raya.

Departemen Pekerjaan Umum (2018), Spesifikasi Umum Perkerasan Aspal, Divisi 6.

Eni, A. (2012), Penggunaan Abu Terbang Dan Abu Batu Kapur Sebagai Tambahan Filler Pada Campuran Hot Rolled Sheet Wearing Course (HRS-WC), Tugas Akhir Fakultas Teknik Universitas Palangka Raya, Palangka Raya.

Muhammad, W, S. (2017), Pengaruh Kadar Filler Abu Batu Kapur Terhadap Karakteristik Marshall Pada Campuran Aspal Beton AC-BC, Teras Jurnal Vol.7, No.1 Fakultas Teknik Universitas Malikussaleh.

Sukirman, S. (2003), Beton Aspal Campuran Panas, Granit, Jakarta.

Suprapto T, M.Sc., (2004), Bahan dan Struktur Jalan Raya, Biro Penerbit KMTS FT UGM.

Zulfikar, S, M. Saleh, Renni Anggraini (2014), Tinjauan Penggunaan Abu Kapur Gamping Sebagai Filler Terhadap Karakteristik Laston Lapis Aus (AC-WC), Jurnal Teknik Sipil Pascasarjana Universitas Syiah Kuala, Banda Aceh. 